\title{
BIOMECHANICAL COMPARATIVE STUDY BETWEEN TENSION BAND WIRING, DOUBLE ENDO BUTTON AND HOOK PLATE FOR ACROMIOCLAVICULAR JOINT INJURY
}

\author{
Erwin Ramawan ${ }^{1 *}$, Jifaldi Afrian MDS $^{2}$ \\ ${ }^{1}$ Department of Orthopaedic and Traumatology, Faculty of Medicine, Universitas Airlangga / \\ Dr Soetomo Hospital, Surabaya \\ ${ }^{2}$ Resident in Department of Orthopaedic and Traumatology, Faculty of Medicine, Universitas \\ Airlangga / Dr Soetomo General Hospital, Surabaya \\ *Correspondence : Erwin Ramawan, Department of Orthopaedic and Traumatology, Faculty of \\ Medicine, Universitas Airlangga/Dr Soetomo Hospital, Surabaya, Jl. Mayjen Prof. Dr. \\ Moestopo 6-7, Surabaya 60286 \\ E-mail: e_ramawan@yahoo.co.id
}

\begin{abstract}
ABSTRAK
Latar Belakang: Teknik operasi baku dalam penanganan cedera sendi acromioclavicular masih diperdebatkan, terdapat pilihan fiksasi antara lain adalah tension band wiring, rekonstuksi AC joint dan hook plate. Ketiga fiksasi ini mampu memberikan fiksasi yang stabil, namun masih didapatkan kontroversi yang menyebutkan keunggulan masing-masing fiksasi tersebut.
\end{abstract}

Tujuan: Mengetahui perbandingan stabilitas biomekanika antara 3 fiksasi yaitu tension band wiring, double endo button dan hook plate sehingga dapat memberikan dasar ilmiah penggunaan fiksasi tersebut.

Metode: Penelitian ini merupakan penelitian eksperimental in vitro. Menggunakan 27 sendi akromioklavikula cadaver dengan tiga kelompok perlakuan yaitu fiksasi tension band wiring, double endo button dan hook plate. Evaluasi pergeseran dengan pengulangan 10x, 20x, 50x dan 100x dengan gaya tarikan $100 \mathrm{~N}$.

Hasil: Pergeseran fiksasi tension band wiring memiliki pergeseran terkecil pada masingmasing pengulangan. Pengulangan 10x rata-rata pergeseran tension band wiring $0,056 \mathrm{~mm}$ $(\mathrm{p}=0.000)$ dibandingkan double endo button $1.622 \mathrm{~mm}$ dan hook plate $0.867 \mathrm{~mm}$. Pengulangan $20 \mathrm{x}$, tension band wiring $0,1667 \mathrm{~mm}(\mathrm{p}=0,000)$ dibandingkan double endo button $3,1778 \mathrm{~mm}$ dan hook plate $1,1111 \mathrm{~mm}$. Pengulangan $50 \mathrm{x}$, tension band wiring $0,3111 \mathrm{~mm}(\mathrm{p}=0.000)$ dengan double endo button $4,7778 \mathrm{~mm}$ dan hook plate $1,3556 \mathrm{~mm}$. Pengulangan 100x, tension band wiring $0,556 \mathrm{~mm}(\mathrm{p}=0.000)$ sedangkan double endo button $5,4444 \mathrm{~mm}$ dan hook plate $1,4556 \mathrm{~mm}$.

Kesimpulan: Secara biomekanik tension band wiring memiliki stabilitas terbaik dibandingkan double endo button dan hook plate. Namun ketiga fiksasi mampu memberikan stabilitas pada gerakan normal sendi acromioklavicular

Kata kunci: cedera sendi akromioklavikula, tension band wiring, double endo button, hook plate

\section{ABSTRACT}

Background: The treatment for acromioclavicular joint injury are debatable, there are fixation options include tension band wiring, AC joint reconstruction and hook plate These fixations are capable of providing a stable fixation, but controversy still exists that mentions the superiority of each of these fixations

Purpose: To compare biomechanical stability of 3 fixation include tension band wiring, double endo button, and hook plate to provide a scientific basis of the fixation. 
Methods: This research is an experimental in vitro. Using 27 acromioclavicular joints cadaver divided into three groups that performed tension band wiring fixation, double endo button and hook plate. Each fixation evaluated with 10, 20, 50 and 100 times repetitions with $100 \mathrm{~N}$ traction force.

Results: Tension band wiring gives the smallest displacement. In 10 times repetition average displacement of tension band wiring $0.056 \mathrm{~mm}(\mathrm{p}=0.000)$ compared to double endo button $1.622 \mathrm{~mm}$ and hook plate $0.867 \mathrm{~mm}$. In 20 times repetitions, tension band wiring $0.1667 \mathrm{~mm}$ $(\mathrm{p}=0,000)$ compared to double endo button $3.1778 \mathrm{~mm}$ and hook plate $1.1111 \mathrm{~mm}$. In 50 times repetition, tension band wiring $0.3111 \mathrm{~mm}(\mathrm{p}=0.000)$ with double endo button $4.7778 \mathrm{~mm}$ and hook plate $1.3556 \mathrm{~mm}$. In 100 times repetitions, tension band wire $0.556 \mathrm{~mm}(\mathrm{p}=0.000)$ while double endo button $5.4444 \mathrm{~mm}$ and hook plate $1.4556 \mathrm{~mm}$.

Conclusion: Tension band wiring have a good stability compared to double endo button and hook plate. But all of fixation provide stability for acriomioclavicular joint motion.

Keywords: acromioclavicular joints injury, tension band wiring, double endo button, hook plate

\section{PENDAHULUAN}

Cedera pada sendi akromioklavikula terjadi pada $12 \%$ cedera di daerah bahu. ${ }^{1}$ Prevalensi ini belum tentu menggambarkan keseluruan pasien karena terkadang pasien dengan cedera ringan jarang mencari pertolongan medis. $^{2} \quad$ Cedera pada sendi akromioklavikula terjadi 5 sampai 10 kali lebih banyak pada pria. Sublukasi sendi akromioklavikula yang disebabkan oleh sprain didapatkan dua kali lebih banyak dibandingkan kasus dislokasi yang disebabkan robekan sendi. Penelitian di Amerika yang melibatkan 520 pemain football dengan cedera bahu, 300 pemain didapatkan kasus sprain atau subluksasi sendi. Cedera bahu memang didapatkan paling banyak pada olahraga yang melibatkan kontak fisik. $^{3}$

Proses penyembuhan cedera sendi akromioklavikula pada kasus derajat berat (klasifikasi Rockwood tipe 3-6) lebih membutuhkan waktu yang lama dibandingkan kasus dislokasi derajat ringan (klasifikasi Rockwood tipe 1-2). Walaupun pada hasil penelitian yang dilakukan Pallis et al tidak didapatkan perbedaan secara statistik namun didapatkan pengobatan pada kasus derajat berat membutuhkan waktu yang lebih lama dengan rata-rata 2,5 bulan, dibanding kasus derajat ringan. ${ }^{4}$ Namun bagi seorang atlet membutuhkan waktu untuk kembali berkompetisi yang lebih cepat.

Penelitian yang dilakukan Kaplan et al mencatat bahwa 93 pemain dengan riwayat cedera sendi akromioklavikula didapatkan $11,8 \%$ menjalani pembedahan (8 reseksi distal clavicular dan 3 prosedur Weaver Dunn). ${ }^{5}$ Pembedahan lebih sering diperlukan pada kasus derajat berat. Sekitar tiga per empat kasus membutuhkan rekonstruksi sendi 
akromioklavikula untuk kembali berkompetisi. Pada derajat ringan hanya $12 \%$ kasus yang menjalani pembedahan. Data ini didasarkan pada penelitian Pallis et al yang melibatkan 336 tim elit antar universitas di Amerika. ${ }^{4}$

Sejumlah teknik bedah telah banyak dilakukan sebagai manajemen cedera sendi akromioklavikula derajat 36. Tujuan utama penanganannya adalah kembalinya fungsi bahu tanpa ada keluhan nyeri. Untuk mendapatkan hal ini diperlukan rekonstruksi secara anatomis dari sendi akromioklavikula baik stabilitas dan geometrinya untuk memungkinkan rehabilitasi dan mobilisasi pada tahap awal pascaoperasi. ${ }^{6}$

Teknik operasi baku dalam penanganan cedera sendi akromioklavikula masih diperdebatkan, terdapat pilihan fiksasi antara lain adalah fiksasi dan reposisi terbuka dengan hook plate $^{6}, \quad$ rekonstuksi sendi akromioklavikula dengan double endo button ${ }^{7}$ dan tension band wiring. ${ }^{8}$ Ketiga fiksasi ini mampu memberikan fiksasi yang stabil, namun masih didapatkan kontroversi yang menyebutkan keunggulan masing-masing fiksasi tersebut.

\section{Cedera Sendi Akromioklavikula}

Cedera sendi akromioklavikula diklasifikasikan oleh Rockwood menjadi
6 tipe berdasarkan pergeseran dan kerusakan ligamen. ${ }^{9}$ Tipe 1 dan 2 adalah dislokasi yang tidak komplit dan tipe 3 hingga 6 adalah dislokasi yang komplit. Cedera tipe I melibatkan kerusakan parsial kapsul sendi di mana tidak ada bukti klinis atau instabiltas secara radiografi. Cedera tipe II mengakibatkan sobekan dari ligamen akromioklavicula tanpa gangguan dari ligamen korakoklavikula. Karena ligamen korakoklavikula masih intak, secara radiografi hanya didapatkan pergeseran minimal pada akromion. Cedera tipe III, baik ligamen akromioklavikula dan korakoklavikula mengalami sobekan kompleks. Ini sering mengakibatkan pergeseran klavikula yang komplit sebesar $100 \%$ ditandai adanya jarak ruang korakoklavikula dibandingkan sisi kontralateral yang normal. Cedera tipe IV ditandai dengan pergeseran ke arah posterior dari distal klavikula, menyebabkan robekan pada fascia otot trapezius. Cedera tipe V mengakibatkan kerusakan ligamen akromioklavikula dan korakoklavikula dengan jarak korakoklavikula antara 100\%-300\% lebih besar dari sisi yang tidak cedera. Kadangkadang, cedera ini mengakibatkan klavikula distal masuk ke dalam fascia deltotrapezial. Jenis cedera tipe VI adalah pergeseran ke arah inferior klavikula 
Artikel Penelitian

Vol 7 No. 1, April 2018

ISSN 2460-8742

http://journal.unair.ac.id/ORTHO@journal-orthopaedi-and-traumatology-surabaya-media-104.html

distal ke posisi subkorakoid. Cedera tipe

VI sangat jarang dijumpai. Cedera tipe

III-VI menyebabkan perlekatan trapezius dan deltoid terlepas dari klavikula distal.

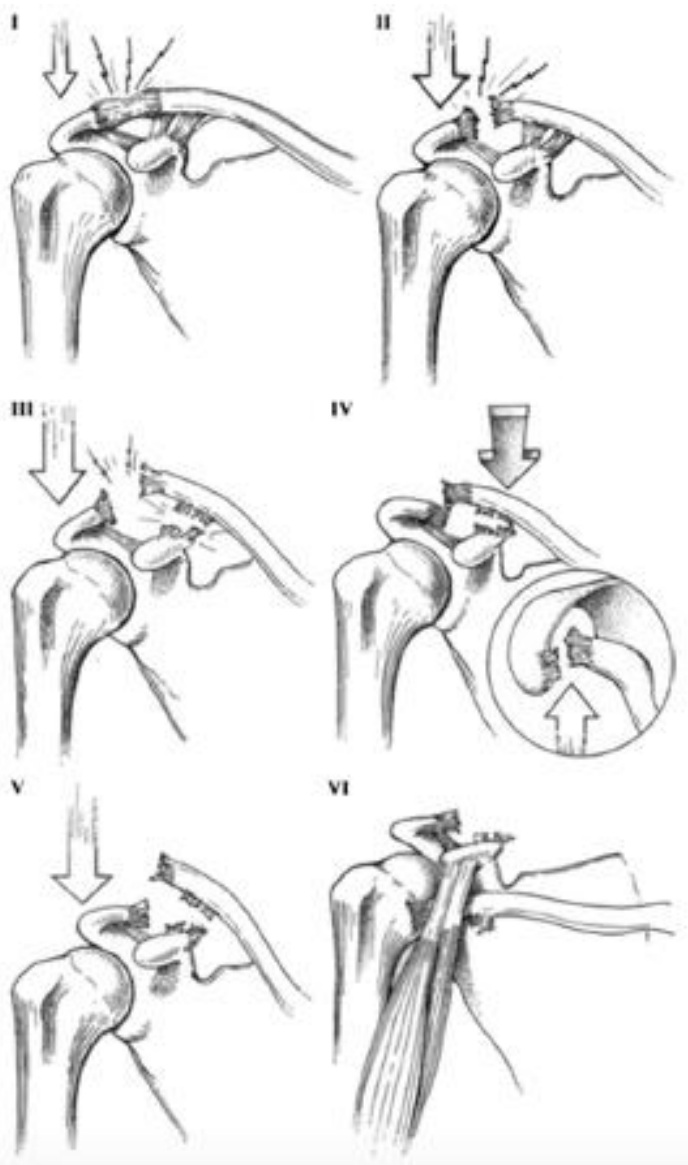

Gambar 1. Klasifikasi cedera sendi akromioklavikula berdasarkan

Rockwood $^{9}$

\section{Pemilihan Implan}

\section{1) Tension band wiring sendi akromioklavikula}

Konsep awal distribusi beban dikembangkan dan dijabarkan oleh Frederic Pauwels, yang mengamati bahwa struktur tabung yang bengkok bila diberikan beban searah sumbu aksial akan memiliki sisi kompresi dan tensi. Berdasarkan pengamatan inilah prinsip fiksasi menggunakan tension band berkembang. ${ }^{8} \quad$ Fiksasi sendi akromioklavikula dengan tension band wiring menggunakan $2 \mathrm{~mm}$ kirshner wire dan 1,2 mm senar wire dengan arah kirshner wire dilakukan menyilang agar mendapatkan kortek tulang pada sisi yang jauh dan meningkatkan pull out strength.
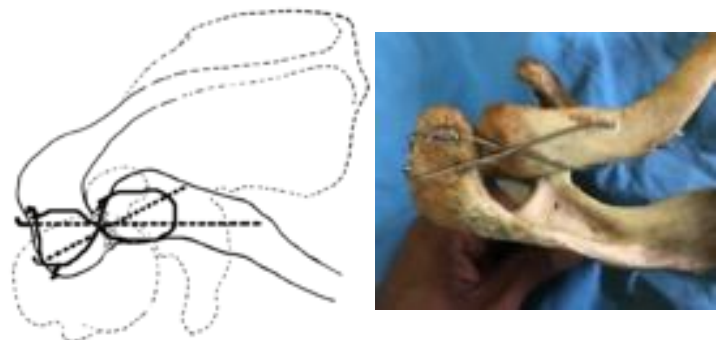

Gambar 2. Fiksasi menggunakan tension band wiring ${ }^{8}$

\section{2) Double endo button sendi}

\section{akromioklavikula}

Penempatan Penempatan fiksasi rekonstruksi dislokasi sendi akromioklavikula dengan double endo button merupakan fiksasi antara klavikula dan korakoid. Fiksasi korakoklavikula memberikan hasil yang baik namun membutuhkan ekspos yang besar sehingga dikembangkan metode minimal invasive dengan menggabungkan teknik fiksasi korakoklavikula dengan teknik rekonstruksi ligamen pada cedera anterior cruciate ligament (ACL). Penggunaan button dan suture pada ACL 
Artikel Penelitian

Vol 7 No. 1, April 2018

ISSN 2460-8742

http://journal.unair.ac.id/ORTHO@journal-orthopaedi-and-traumatology-surabaya-media-104.html

dikombinasikan dengan prinsip fiksasi

korakoklavikula. $^{7}$

Pengeboran menggunakan mata bor 4,5 mm. Implan dimasukkan pada sisi klavikula dengan bantuan alat, dan menarik benang yang dapat membawa button ke sisi superior klavikula. ${ }^{7}$ Sebelum melakukan pembuatan simpul, dilakukan reposisi dari sendi akromioklavikula. Pembuatan simpul minimal sebanyak 5 kali.

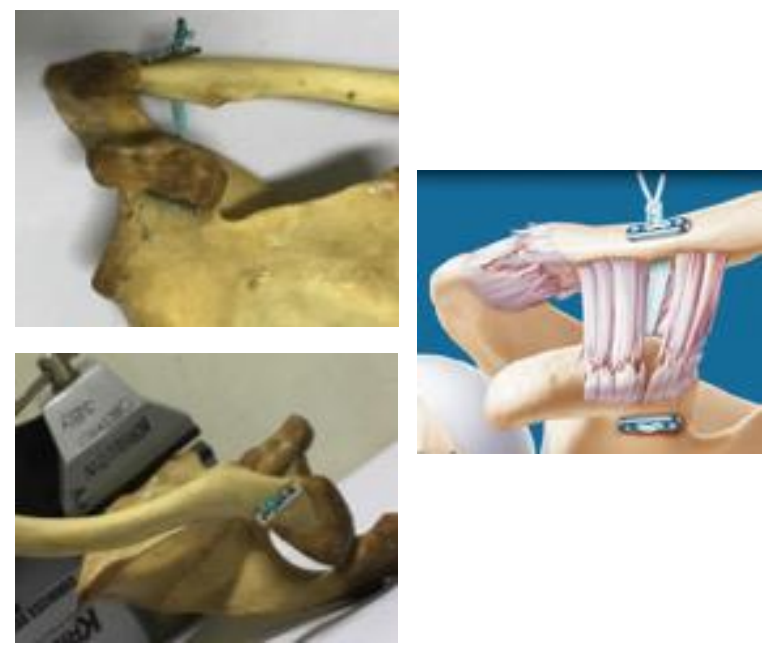

Gambar 3. Fiksasi menggunakan double endo button ${ }^{7}$

\section{3) Hook Plate sendi akromioklavikula}

Penempatan fiksasi hook plate mencakup acromion. Sisi hook atau pengait berada pada akromion. Sisi medial disesuaikan panjangnya minimal pemasangan 3 screw. Reposisi terlebih dahulu dilakukan menggunakan pointed clamp kemudian fiksasi menggunakan hook plate. ${ }^{6}$
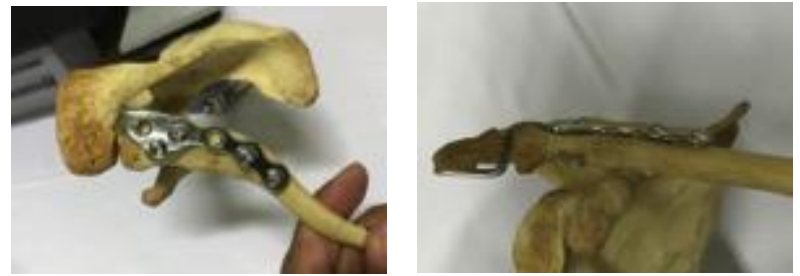

Gambar 4. Fiksasi menggunakan hook

$$
\text { plate }^{6}
$$

\section{METODOLOGI PENELITIAN}

Penelitian ini merupakan penelitian eksperimental in vitro dengan rancangan Randomized Control Post Test-Only Grup Design. Dibagi menjadi 3 kelompok: kelompok fiksasi tension band wiring, fiksasi dengan double endo button dan kelompok fiksasi hook plate. Tiap kelompok dibandingkan displacement (pergeseran) fragmen setelah dilakukan fiksasi dan pemberian beban berulang. Pergeseran dinilai adanya pergeseran titik pada akromion ke arah inferior terhadap klavikula diukur dengan membandingkan jarak antara kedua titik sebelum dan sesudah diberikan pembebanan berulang.

Sendi akromioklavikula berperan dalam menahan gaya beban pada saat abduksi dan elevasi 180 derajat gerakan 
scapula ke arah inferior. ${ }^{10}$ Beban diberikan sebesar 100N, yang kemudian diulang berkala, sebesar 10x, 20x, 50x, dan 100x. Unit eksperimen pada penelitian ini sendi akromioklavikula (tulang scapula-clavicula) kadaver lakilaki berusia antara 20-60 tahun yang meninggal dalam kurun waktu kurang dari 3 tahun lalu.

Data yang terkumpul akan dianalisis secara statistik menggunakan program SPSS 23. Pada penelitian ini didapatkan data berupa kualitatif. Uji normalitas dilakukan dengan menggunakan Shapiro-Wilk. Apabila data terdistribusi normal dilakukan uji parametrik menggunakan uji ANOVA, apabila data tidak terdistribusi normal dilakukan uji non parametric KruskalWallis. Untuk mengetahui perbandingan antar fiksasi dilakukan uji Tukey.

\section{HASIL}

Hasil penelitian menunjukkan fiksasi menggunakan tension band wiring memiliki pergeseran terkecil dibandingkan double endo button dan hook plate. Pergeseran rata-rata tiap pengulangan pada tension band wiring didapatkan antara 0,05-0,55 $\mathrm{mm}$, hook plate antara $0,86-1,45 \mathrm{~mm}$ dan double endo button antara 1,62-5,44 $\mathrm{mm}$ (Gambar 5).

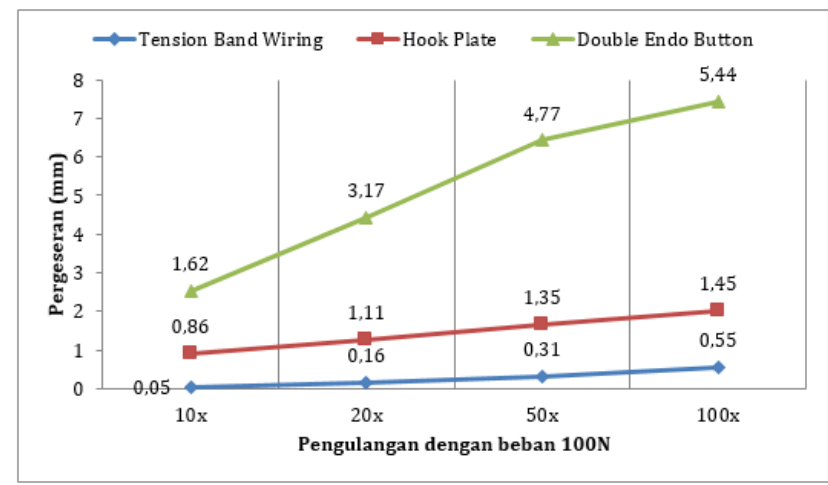

Gambar 5. Grafik perbandingan pergeseran sendi akromioklavikula antar fiksasi

\section{Uji Normalitas}

Uji normalitas Shapiro-Wilk ddapatkan pada pengulangan $10 \mathrm{x}$ data tidak terdistribusi normal tension band wiring, $\quad \mathrm{p}=0.005 \quad(\mathrm{p}<0.05) \quad$ dan pengulangan 20x, 50x dan 100x data terdistribusi normal. Pada pengulangan 10x dilakukan uji komparasi non parametrik menggunakan uji KruskalWallis, sedangkan pada pengulangan 20x, 50x dan 100x dapat dilanjutkan uji komparasi parametrik menggunakan uji ANOVA.

\section{Uji Komparatif}

Pada pengulangan 10x menggunakan uji Kruskal-Wallis (Tabel 1) hasil perbedaaan bermakna pada ketiga fiksasi $(p=0.000)$, fiksasi tension band wiring memiliki nilai peringkat rata-rata terkecil $(5,06)$ diikuti fiksasi hook plate $(16,22)$ 
Artikel Penelitian

Vol 7 No. 1, April 2018

ISSN 2460-8742

http://journal.unair.ac.id/ORTHO@journal-orthopaedi-and-traumatology-surabaya-media-104.html

dan peringkat rata-rata terbesar adalah double endo button $(20,72)$.

Tabel 1. Hasil uji Kruskal-Wallis fiksasi tension band wiring, double endo button dan hook plate pada pengulangan $10 \mathrm{x}$

\begin{tabular}{|c|c|c|c|}
\hline $\begin{array}{c}\text { Uji } \\
\text { Tarik } \\
\mathbf{1 0 0} \mathbf{N}\end{array}$ & $\begin{array}{c}\text { Jenis } \\
\text { Implan }\end{array}$ & $\begin{array}{c}\text { Peringkat } \\
\text { rata-rata }\end{array}$ & $\boldsymbol{p}$ \\
\hline $10 \mathrm{x}$ & $\begin{array}{c}\text { Tension } \\
\text { Band } \\
\text { Wiring }\end{array}$ & 5,06 & \multirow{2}{*}{0,000} \\
\cline { 2 - 3 } & $\begin{array}{c}\text { Double } \\
\text { Endo } \\
\text { Button }\end{array}$ & 20,72 & \\
& $\begin{array}{c}\text { Hook } \\
\text { Plate }\end{array}$ & 16,22 & \\
\hline
\end{tabular}

Selanjutnya untuk mengetahui perbandingan antar dua fiksasi dilakukan uji post hoc untuk menentukan signifikansi antar kelompok perlakuan. Dengan menggunakan uji Mann-Whitney didapatkan hasil yang bermakna pada semua kelompok perbandingan (Tabel 2). Fiksasi tension band wiring memiliki nilai peringkat rata-rata paling rendah. Hal ini menunjukkan bahwa secara biomekanik tension band wiring lebih stabil dibandingkan fiksasi hook plate dan double endo button.
Tabel 2. Hasil uji post hoc Mann-

Whitney antar perlakuan pada pengulangan $10 \mathrm{x}$

\begin{tabular}{|c|c|c|c|}
\hline $\begin{array}{c}\text { Uji } \\
\text { Tarik } \\
100 \mathrm{~N}\end{array}$ & $\begin{array}{c}\text { Jenis } \\
\text { Implan }\end{array}$ & $\begin{array}{l}\text { Peringkat } \\
\text { Rata-rata }\end{array}$ & $p$ \\
\hline \multirow[t]{2}{*}{$10 x$} & $\begin{array}{c}\text { Tension } \\
\text { Band } \\
\text { Wiring }\end{array}$ & 14,00 & \multirow[t]{2}{*}{0,000} \\
\hline & $\begin{array}{c}\text { Double } \\
\text { Endo } \\
\text { Button }\end{array}$ & 5,00 & \\
\hline \multirow[t]{2}{*}{$10 \mathrm{x}$} & $\begin{array}{c}\text { Double } \\
\text { Endo } \\
\text { Button }\end{array}$ & 11,72 & \multirow[t]{2}{*}{0,076} \\
\hline & $\begin{array}{l}\text { Hook } \\
\text { Plate }\end{array}$ & 7,28 & \\
\hline \multirow[t]{2}{*}{$10 \mathrm{x}$} & $\begin{array}{c}\text { Tension } \\
\text { Band } \\
\text { Wiring }\end{array}$ & 5,06 & \multirow[t]{2}{*}{0,000} \\
\hline & $\begin{array}{l}\text { Hook } \\
\text { Plate }\end{array}$ & 13,94 & \\
\hline
\end{tabular}

Pada pengulangan 20x, 50x dan 100x dengan menggunakan uji ANOVA (Tabel 3) didapatkan perbedaan bermakna antar fiksasi. Pengulangan 20x $\mathrm{p}=0,000$, pengulangan $50 \mathrm{x} \mathrm{p}=0,000$ dan pengulangan 100x $\mathrm{p}=0,000$. Dimana perbandingan rata-rata terkecil didapatkan pada fiksasi tension band wiring pada semua pengulangan, diikuti fiksasi hook plate pada semua pengulangan dan rata-rata terbesar pada double endo button pada semua pengulangan. 
Artikel Penelitian

Vol 7 No. 1, April 2018

ISSN 2460-8742

http://journal.unair.ac.id/ORTHO@journal-orthopaedi-and-traumatology-surabaya-media-104.html

Tabel 3. Hasil uji ANOVA biomekanik

fiksasi tension band wiring, double endo button dan hook plate pada pengulangan

20x, 50x dan 100x

\begin{tabular}{|c|c|c|c|}
\hline $\begin{array}{c}\text { Uji } \\
\text { Tarik } \\
\mathbf{1 0 0} \mathbf{N}\end{array}$ & $\begin{array}{l}\text { Jenis } \\
\text { Implan }\end{array}$ & $\begin{array}{l}\text { Rerata } \\
(\mathbf{m m})\end{array}$ & $p$ \\
\hline \multirow[t]{3}{*}{$20 x$} & $\begin{array}{c}\text { Tension } \\
\text { Band } \\
\text { Wiring }\end{array}$ & $\begin{array}{c}0,1667 \pm \\
0,111\end{array}$ & \multirow[t]{3}{*}{0,000} \\
\hline & $\begin{array}{l}\text { Double } \\
\text { Endo } \\
\text { Button }\end{array}$ & $\begin{array}{c}3,1778 \pm \\
0,641\end{array}$ & \\
\hline & Hook Plate & $\begin{array}{c}1,1111 \pm \\
0,459\end{array}$ & \\
\hline \multirow[t]{3}{*}{$50 \mathrm{x}$} & $\begin{array}{c}\text { Tension } \\
\text { Band } \\
\text { Wiring }\end{array}$ & $\begin{array}{c}0,3111 \pm \\
0,145\end{array}$ & \multirow[t]{3}{*}{0,000} \\
\hline & $\begin{array}{c}\text { Double } \\
\text { Endo } \\
\text { Button }\end{array}$ & $\begin{array}{c}4,7777 \pm \\
0,607\end{array}$ & \\
\hline & Hook Plate & $\begin{array}{c}1,3556 \pm \\
0,497\end{array}$ & \\
\hline \multirow[t]{3}{*}{$100 x$} & $\begin{array}{c}\text { Tension } \\
\text { Band } \\
\text { Wiring }\end{array}$ & $\begin{array}{c}0,5556 \pm \\
0,251\end{array}$ & \multirow[t]{3}{*}{0,000} \\
\hline & $\begin{array}{l}\text { Double } \\
\text { Endo } \\
\text { Button }\end{array}$ & $\begin{array}{c}5,4444 \pm \\
0,709\end{array}$ & \\
\hline & Hook Plate & $\begin{array}{c}1,4556 \pm \\
0,502\end{array}$ & \\
\hline
\end{tabular}

Keterangan: $\mathrm{p}<0,05$ menunjukkan perbedaan bermakna

Selanjutnya dilakukan uji post hoc dengan uji Tukey pada pengulangan 20x, 50x dan 100x (Tabel 4). Antara fiksasi double endo button dengan tension band wiring didapatkan hasil bermakna dengan rata-rata 3,0111 $\mathrm{mm}(20 \mathrm{x}) ; 4,4666 \mathrm{~mm}$ (50x) dan 4,8888 mm (100x) dan fiksasi hook plate dan tension band wiring didapatkan hasil yang bermakna dengan rata-rata $0,9444 \mathrm{~mm}(20 \mathrm{x}) ; 1,0444 \mathrm{~mm}$ (50x) dan 0,9 mm (100x). Hal ini menunjukkan tension band wiring memiliki pergeseran yang lebih kecil dibandingkan double endo button dan hook plate. Sedangkan perbandingan antara hook plate dan double endo button didapatkan pergeseran yang lebih kecil pada hook plate, 2,0667 mm (20x), $3,4222 \mathrm{~mm}(50 \mathrm{x})$ dan 3,9888 mm (100x).

Tabel 4. Hasil uji Tukey antar fiksasi pada pengulangan 20x, 50x dan 100x

\begin{tabular}{|c|c|c|c|}
\hline \multicolumn{2}{|c|}{$\begin{array}{l}\text { Perbandingan } \\
\text { antar fiksasi }\end{array}$} & $\begin{array}{c}\text { Perbandingan } \\
\text { rerata }(\mathrm{mm}) \\
( \pm 0,2169)\end{array}$ & $p$ \\
\hline \multicolumn{4}{|c|}{ Pengulangan 20x } \\
\hline $\begin{array}{l}\text { Double } \\
\text { Endo } \\
\text { Button }\end{array}$ & $\begin{array}{c}\text { Tension } \\
\text { Band } \\
\text { Wiring }\end{array}$ & 3,0111 & 0,000 \\
\hline $\begin{array}{l}\text { Hook } \\
\text { Plate }\end{array}$ & $\begin{array}{c}\text { Tension } \\
\text { Band } \\
\text { Wiring }\end{array}$ & 0,9444 & 0,001 \\
\hline $\begin{array}{l}\text { Double } \\
\text { Endo } \\
\text { Button }\end{array}$ & $\begin{array}{l}\text { Hook } \\
\text { Plate }\end{array}$ & 2,0667 & 0,000 \\
\hline \multicolumn{4}{|c|}{ Pengulangan 50x } \\
\hline $\begin{array}{l}\text { Double } \\
\text { Endo } \\
\text { Button }\end{array}$ & $\begin{array}{c}\text { Tension } \\
\text { Band } \\
\text { Wiring }\end{array}$ & 4,4666 & 0,000 \\
\hline $\begin{array}{l}\text { Hook } \\
\text { Plate }\end{array}$ & $\begin{array}{c}\text { Tension } \\
\text { Band } \\
\text { Wiring }\end{array}$ & 1,0444 & 0,001 \\
\hline $\begin{array}{l}\text { Double } \\
\text { Endo } \\
\text { Button }\end{array}$ & $\begin{array}{l}\text { Hook } \\
\text { Plate }\end{array}$ & 3,4222 & 0,000 \\
\hline \multicolumn{4}{|c|}{ Pengulangan 100x } \\
\hline $\begin{array}{l}\text { Double } \\
\text { Endo } \\
\text { Button }\end{array}$ & $\begin{array}{c}\text { Tension } \\
\text { Band } \\
\text { Wiring }\end{array}$ & 4,8888 & 0,000 \\
\hline $\begin{array}{l}\text { Hook } \\
\text { Plate }\end{array}$ & $\begin{array}{c}\text { Tension } \\
\text { Band } \\
\text { Wiring }\end{array}$ & 0,9000 & 0,003 \\
\hline
\end{tabular}


Artikel Penelitian

Vol 7 No. 1, April 2018

ISSN 2460-8742

http://journal.unair.ac.id/ORTHO@journal-orthopaedi-and-traumatology-surabaya-media-104.html

\begin{tabular}{|c|c|c|c|}
\hline $\begin{array}{c}\text { Double } \\
\text { Endo } \\
\text { Button }\end{array}$ & $\begin{array}{c}\text { Hook } \\
\text { Plate }\end{array}$ & 3,9888 & 0,000 \\
\hline
\end{tabular}

Keterangan: $\mathrm{p}<0,05$ menunjukkan

perbedaan bermakna

\section{PEMBAHASAN}

Nilai rata-rata fiksasi menggunakan tension band wiring memiliki pergeseran terkecil dibandingkan fiksasi double endo button dan hook plate pada semua pengulangan. Sehingga dapat dikatakan tension band wiring adalah fiksasi paling rigid dibandingkan double endo button dan hook plate. Pengulangan 100x merupakan uji yang memberikan pergeseran maksimal. Didapatkan hasil pergeseran pada fiksasi tension band wiring sebesar $0,5556 \mathrm{~mm}$, hook plate sebesar 1,4556 $\mathrm{mm}$ dan double endo button sebesar 5,4444 mm. Pergeseran yang didapatkan pada penelitian ini masih berada pada fungsi normal sendi akromioklavikula yaitu antara 4-6 mm. ${ }^{11}$

Penelitian yang dilakukan Fukuda memberikan hipotesa jika ingin mendapatkan kekuatan maksimal penyembuhan sendi akromioklavikula maka perlu mengikutsertakan seluruh ligamen dalam proses penyembuhan. Sehingga dalam melakukan pengobatan sebaiknya merujuk pada penyembuhan ligamen pada sendi akromioklavikula. Fukuda menjelaskan juga bahwa ligamen akromioklavikula berkontribusi 50\% dari seluruh gerakan rotasi axial posterior pada pergeseran superior $(65 \%){ }^{12}$ Kontribusi gaya ligamen conoid menahan pergeseran superior sebesar 60\% dari gaya keseluruhan. ${ }^{10}$ Ketiga fiksasi memberikan fiksasi yang stabil untuk membantu proses penyembuhan ligamen

Yoon JP et al merekomendasikan penggunaan hook plate ${ }^{6}$ karena keuntungan fiksasi yang rigid dan secara biomekanik menyerupai gerakan normal sendi akromioklavikula. ${ }^{13}$ Pada penelitian ini didapatkan rata-rata pergeseran 0,86-1,45 mm. Beberapa komplikasi yang terjadi seperti keradangan tendon supraspinatus atau bursa subakromion. Namun komplikasi ini dapat dihindari dengan pengambilan implan 12-14 minggu pascaoperasi. ${ }^{14}$

Petersen et al merekomendasikan teknik rekonstruksi AC joint dengan prosedur yang minimal invasive sehingga kerusakan jaringan lunak dapat dikurangi serta waktu pengerjaan yang lebih cepat. Komplikasi saat proses pengeboran pada sisi korakoid seperti lesi neurovaskular dapat dihindari dengan menggunakan alat pelindung di sisi inferior korakoid. ${ }^{7}$ Namun perlu diperhatikan resiko pengeboran pada klavikula dapat menyebabkan patah tulang iatrogenik di kemudian hari. ${ }^{15}$ 
Artikel Penelitian

Vol 7 No. 1, April 2018

ISSN 2460-8742

http://journal.unair.ac.id/ORTHO@journal-orthopaedi-and-traumatology-surabaya-media-104.html

Sedangkan Jambukeswaran et al merekomendasikan penggunakan tension band wiring karena memberikan hasil yang sama dengan keuntungan teknik yang lebih mudah dan bahan yang mudah didapatkan. ${ }^{8}$ Komplikasi yang kadang terjadi seperti patahnya implan kirshner wire atau migrasi implan. Osteoarthritis sendi kadang juga terjadi akibat pengeboran implan di dalam sendi. ${ }^{16}$

Proses penyembuhan kapsul sendi akan lebih baik apabila terdapat stres mekanis melalui beban fungsional sehingga meningkatkan orientasi serat kolagen dan meningkatkan kepadatannya. Sebaliknya, apabila dilakukan imobilisasi terjadi proses katabolisme yang menghambat penyembuhan kaspul sendi, dan meningkatkan degradasi dari struktur pembangun sendi sehingga menyebabkan atrofi yang progresif dengan hasil akhir kurangnya tensile strength dari kapsul sendi. ${ }^{17}$ Sehingga dapat dikatakan pergeseran yang minimal membantu proses penyembuhan dari kapsul sendi.

Secara mikroskopis, kapsul sendi memiliki komposisi yang sama dengan tendon dan ligamen, dimana terdapat jaringan fibrokartilago sebagai pembentuk utama. Jaringan fibrokartilago tersebut terdiri dari glikosaminoglikan dan beberapa dari kolagen tipe $2 .{ }^{18}$ Matrik ekstraselular yang terdapat pada fibrokartilago kapsul sendi yaitu khondroitin sulfat, keratin sulfat dan dematan sulfat. ${ }^{19}$ Respon selular akan meningkat apabila mendapatkan gaya tarikan.

\section{KESIMPULAN DAN SARAN}

Penelitian ini menunjukkan bahwa secara biomekanik fiksasi tension band wiring memiliki stabilitas terbaik dibandingkan fiksasi double endo button dan hook plate. Serta menunjukkan bahwa ketiga fiksasi dapat mempertahankan sendi akromioklavikula dalam rentang gerakan normal. Namun perlu perlu diperhatikan komplikasi yang dapat terjadi pada masing-masing fiksasi.

Penelitian klinis prospektif lanjutan diperlukan untuk menilai stabilitas, derajat fungsi, jangka waktu operasi dan komplikasi fiksasi tension band wiring, double endo button dan hook plate pada cedera sendi akromioklavikula derajat 3-6.

\section{REFERENSI}

1. Emery R. 1997. Acromioclavicular and sternoclavicular joints. In: Copeland S, ed. Shoulder surgery. London: WB Saunders, 1997 
http://journal.unair.ac.id/ORTHO@journal-orthopaedi-and-traumatology-surabaya-media-104.html

2. Rockwood CA, Williams G, Young D. Disorders of the acromioclavicular joint. In: Rockwood CA, Matsen FA, eds. The shoulder. Second ed. Vol. 1. Philadelphia: WB Saunders, 1998:483-553

3. Webb J, Bannister G. 1992. Acromioclavicular disruption in first class rugby players. Br J Sports Med $1992 ; 26: 247-8$

4. Pallis M, Cameron KL, Svoboda SJ, Owens BD. 2012. Epidemiology of Acromioclavicular Joint Injury in Young Athletes. Am J Sports Med 2012;40-2072

5. Kaplan LD, Flanigan DC, Norwig J, Jost P, Bradley J. 2005. Prevalence and variance of shoulder injuries in elite collegiate football players. Am J Sports Med. 2005;33(8):1142-1146

6. Yoon JP, Lee BJ, Nam JS, Chung SW, Jeong WJ, Min WK, Oh JH. Comparison of result between ook plate fixation and ligament reconstruction for acute unstable acromioclavicular joint dislocation. Clinics in Orthopedic Surgery 2015;7:97-103

7. Petersen W, Wellmann M, Rosslenbroich S, Zantop T. 2010. Minimally Invasive Acromioclavicular Joint

Reconstruction (MINAR). Open Orthop Traumatol. 2010 Mar;22(1):52-61

8. Jambukeswaran PST, Senthilnathan, Prabhajar R. 2016. Comparison between two surgical technique acromioclavicular tension band wiring and acromioclavicular screw fixation in acromioclavicular dislocations. Int. J. Modn. Res. Revs. Volume 4, Issue 11, pp 1388-1391

9. Tossy JD, Mead NC, Sigmond HM. Acromioclavicular separations: Useful and practical classification for treatment. Clin Orthop Relat Res. 1963;28:111-9.

10. Mazzocca AD, Arciero RA, Bicos J. 2007. Evaluation and treatment of acromioclavicular joint injuries. Am J Sports Med 2007;35-2

11. Warth RJ, Martetschkager F, Gaskill TR, Millett PJ. 2012. Acromioclavicular joint separations. Curr Rev Musculoskelet Med (2013) $6: 71-78$

12. Kwon YW, Iannotti JP. 2003. Operative treatment of acromioclavicular joint injuries and results. Clin Sports Med. 2003;22:291-300.

13. McConnell AJ, Yoo DJ, Zdero R, Schemitsch EH, McKee MD. 2007. Methods of operative fixation of the 
Artikel Penelitian

Vol 7 No. 1, April 2018

ISSN 2460-8742

http://journal.unair.ac.id/ORTHO@journal-orthopaedi-and-traumatology-surabaya-media-104.html

acromio-clavicular joint: a biomechanical comparison. J Orthop

Trauma. 2007 Apr; 21(4):248-53

14. Kumar N, Sharma V. 2015. Hook plate fixation for acute acromioclavicular dislocations without korakoklavikula ligament reconstruction: a functional outcome study in military personel. Strategies Trauma Limb Reconstr. 2015 Aug; 10(2): 79-85

15. Moodie JAF, Shortt NL, Robinson CM. 2008. Injuries to the acromioclavicular joint. J Bone Joint Surg [Br] 2008;90-B:697-707.

16. Li Xinning, Ma R, Bedi A, Dines DM, Altchek DW, Dines JS. 2014. Current Concepts Review; Management of Acromioclavicular Joint Injuries. J Bone Joint Surg [Am] 2014;96:73-84.

17. Browner BD, Jupiter JB, Krettek, Anderson PA. 2015. Skeletal Trauma: Basic Science, Management, and Reconstruction.

18. Sugathan HK, Dodenhoff RM. 2012. Management of type 3 acromioclavicular joint dislocation: Comparison of Long-Term Functional Results of Operative Methods. International Scholarly Research Network, 2012;580504-6
19. Benjamin M, Ralphs Jr, Shibu M, Irwin M. 1993. Capsular tissues of the proximal interphalangeal joint: normal composition and effects of Dupuytren's disease and rheumatoid arthritis. Journal of Hand Surgery 18B, 371-376 